\title{
INTERSEXUALITY IN RANA CANTABRIGENSIS ${ }^{1}$
}

\author{
TSO-HSIN CHENG \\ University of Michigan
}

FIVE FIGURES

AUTHOR'S ABSTRACT

The specimen described presents a typical intersexual condition, in which not only the primary sex chrracters, but also the accessory sex organs and the secondary sex characters are of a mixed type. Both gonads are ovotestes, in which the ovarian as weil as the testicular tissues are morphologicaly normal, but functionally underdeveloped. Stromal hypelplasia is distinct, especially so in the left gonad; it is probably a functional factor in the

generative process of the spermatic tissue.

Sex transformation in the intersexual frogs may probably be initiated by an abnormality in sex differentiation or in the genetical constitution of sex, and is only subsequently influenced and modified by environmental action. Absolute dominancy of male sex in the process of sex transformation is questionable. There are indications that in frogs sex transformation may possibly occur in a female direction.

Sex-organ anomaly in anurans was first recorded by Spengel in 1876. Since then numerous cases have been recorded, most of which have been classed as abnormal hermaphrodites. These hermaphrodites may be regarded as intersexual forms, the generative systems of which come to possess elements of both sexes, probably through a genetical abnormality in the sex constitution of the zygote, or through some defective embryonic physiological mechanism inducing a certain specific derangement during sex differentiation, or through environmental influences, as advocated by many, or through any combination of the above factors. Crew ('21 b), in his review of the recorded cases of abnormality of the reproductive system in frogs and toads, enumerated forty cases. Swingle ('22) added another case described in the bullfrog (apparently by Clemens, '21), making a total of forty-one. This number, in consequence, has frequently been referred to as a complete record of known cases up to 1921. A search of literature, however, reveals numerous cases which both of the

${ }^{1}$ Contribution from the Zoölogical Laboratory of the University of Michigan. 
above-mentioned writers have apparently overlooked. Balbiani ('79), Hoffmann ('86), Beard (Cole, '96), ${ }^{2}$ Friedmann ('98 a), and Champy ('13) reported the occurrence of ovarian elements in the testes of anurans; Pflüg'er ('82), Meyer (Spengel, '84), ${ }^{3}$ Eismond ('92), ${ }^{4}$ Friedmann ('98 b), King' ('10), Swingle ('17), and Witschi ('14, '21) observed the same phenomenon among frogs. Matthews ('85) noted the presence of 'ovaries' and more or less perfect müllerian ducts in a great number of male toads. Ikeda ('96) recorded hermaphroditism in the Japanese toads, Goodall ('08), in Rana temporaria, and Yung ('07), in Rana esculenta, in which species Kuschakewitsch ('11) also found a lateral hermaphrodite. Loisel ('01) described a female frog of Rana temporaria which possessed very degenerate ovaries and male secondary sex characters. Nussbaum ('06, '12) noticed in Rana fusca abnormal conditions of testes in forms of hypertrophy, atrophy, and multiplicity. Of the last phenomenon, Gerhartz ('06) also recorded two specimens. Fuhrmann ('13) presented forty interesting cases of hermaphrodite toads, ranging from 'hermaphrodisme rudimentaire' to 'hermaphrodisme effectif.' Heymons ('17) reported a male frog (Rana temporaria) in which the right gonad was a hypertrophied testis, while the left one was filled with dark brown globules, müllerian ducts of the female type being present. Patzelt ('18) described an adult female of Rana esculenta with rudimentary ovaries and small oviducts; Bhattacharya and Das ('20), an adult male of Rana tigrina with testicular atrophy and imperfectly developed müllerian ducts; Lloyd ('21), a male frog of Rana temporaria possessing only one greatly enlarged testis. Takahashi, in 1915, found two cases of intersexuality in Bufo bufo japonicus and, in 1917, five more in the same species and, besides, one case in Rana limnocharis. Accord-

\footnotetext{
a Cole mentioned that Doctor Beard had observed well-developed ova in the testis of the toad quite apart from Bidder's organ.

${ }^{3}$ According to Spengel, Fr. Meyer had informed him, "dass nach seinen Erfahrungen sehr häufig bei Fröschen Hoden mit Ovarialeinschlüssen und umgekehrt Ovarien mit Hodeneinsehlüssen vorkämen.",

'Data from Mitrophanow ('94), Cole ('96), and Ognew ('06).
} 
ing to Harms ('21 a), "In der Umgebung von Marburg findet man nicht selten äusserlich männlich aussehende Kröten ... . , die zwischen Hoden und Bidderschem Organ entweder einseitig oder beiderseitig ein mehr oder weniger grosses Ovarium besitzen." Harms ('21 b) also reported castration experiments on some glandular hermaphrodites of toads. In view of the above brief résumé of the more important literature, it becomes evident that Crew-Swingle's list of forty-one cases is by no means complete; on the contrary, it represents but a fraction of the large number of cases known up to that time.

Since 1921, more cases of abnormal sex organs have been described in frogs and toads. Cunningham and Becton ('26), Caroli ('26 a, b; '27), and Stohler ('28) found female elements in the male gonads of Bufo. The last-named author also claimed that he had found a 'genetischen Hermaphrodit' possessing the functional as well as potential units of both sexes. Guyénot and Ponse ('23 b) recorded two hermaphrodite toads from which they had removed the testes. Harms ('26) found 1 per cent of intersexuality among male toads in Königsberg. Eggert ('26, '27, '29) reported many cases of intersexuality in Bufo vulgaris, and ('29) one case in Rana temporaria. Caroli ('26 c) observed, in the left kidney of a sexually mature male toad, a globular formation composed of spermatozoa, spermatocytes, and spermatogonia. Van Oordt ('22) found in Rana fusca numerous eggs in the right testis of an otherwise normal male. Witschi ('21, '23) described cases of hermaphrodites which he regarded as masculinized females. The same author ('24) discussed some gonadic anomalies, the cause of which he attributed to the influence of delayed fertilization of the eggs concerned. Crew and Fell ('22) found in a male of Rana temporaria a displaced testis which contained many large bodies closely resembling ova. According to the authors, these ovum-like bodies were not ovarian in nature, but were merely a product of liquefaction of the degenerating spermatozoa. Rau and Gatenby ('23) described a partially hermaphroditic frog and mentioned in passing that 
in Bufo some rare instances of hermaphroditism had been observed during their study. In Rana esculenta, Patzelt ('23) noted two cases of testicular atrophy; Dornesco ('26, '27), two of congenital monorchidism, and Dubois et Ponse ('27), five of hypogenitalism. In Rana temporaria, Dauvart ('26, '27) recorded two specimens of heterotopic testis, and Shaw and Brambell ('28), one of aberrant ovary. In Rana pipiens, Maclean ('28) reported a male frog possessing müllerian ducts of female type. Chidester ('26) stated that in two adult male bullfrogs normal eggs were discovered embedded in the wall of the digestive tubes, attached to the fatbodies and enmeshed in the peritoneum and mesentery. In Rana catesbiana, Swingle ('26) found oocyte-like cells in adult testes and described some larval gonads which were "neither truly female or male, but strongly intersexual, with female characters predominating." Other cases of abnormal frogs with ovotesticular gonads were recorded by Leigh-Sharpe ('22) (species not mentioned), Neal' ('24) in Rana pipiens, and Woronzowa ('26), Draigoiu et Pop ('27), and Lloyd ('29), in Rana temporaria. Of all the forms hitherto described, only a few belong to the American species. In this paper is presented the first record of intersexuality in the American wood frog, Rana cantabrigensis.

\section{DESCRIPTION}

The animal to be deseribed was caught, together with a number of other wood frogs, in the afternoon of September 29,1928 , in a pond of White Woods in the vicinity of Ann Arbor, Michigan. It was killed the following evening in Bouin's fixing fluid and preserved in 75 per cent alcohol, where it remained until recently, when the writer began examining and sectioning the frogs in his study of the seasonal variations of the gonads. The intersexual nature of

"The author spoke of a large Bidder's organ associated with the left testis. What he meant by Bidder's organ might be an abnormal ovary. It is now generally agreed that Bidder's organ as such does not occur in Rana. According to Müller ('30), a rounded body was found present at the anterior end of the testes in frog tadpoles. His observation has not been confirmed. 
the frog first manifested itself in the gonads, which in size were testicular, while in texture distinctly ovarian, except for the posterior portion of the left gonad. Upon closer examination, rudimentary müllerian ducts were found present along the outer border of both kidneys. From these preliminary findings, the author deemed it worth while to make a detailed study, the results of which are embodied in the following description.

\section{External characters}

The specimen was a full-sized adult frog. It measured 36 $\mathrm{mm}$. from the tip of the snout to the posterior surface of the ischial symphysis. Measurements of scores of wood frogs killed at different times of the year showed that the average body length in males was approximately $38 \mathrm{~mm}$. and in females, nearly $42 \mathrm{~mm}$. The difference, though considerable, cannot, however, be considered significant for identifying sex in any particular case, since males and females frequently merge into the length range of the opposite sex. In color, the frog was grayish, with a darker color along the midline of the back and with black bars and spots on both hind limbs. Such coloration is characteristic of many females, though also present in some males; but it is decidedly different from the extreme dark condition so typical of many males at this season. In body build the frog resembled more a small female than a male of about the same age. The skin of the back and along the upper surface of the hind limbs was roughened with many distinct papillae having the appearance of small, rounded, pale grayish or white, warty growths. These papillae were most dense around the anal region, becoming more and more scattered anteriorly until totally absent at some distance behind the eyes. Along the sides of the trunk a few larger elevations were noticed. The distribution of the papillae as a whole suggested femaleness. In males such papillae, as a rule, are absent, and, if present, are usually scanty. 

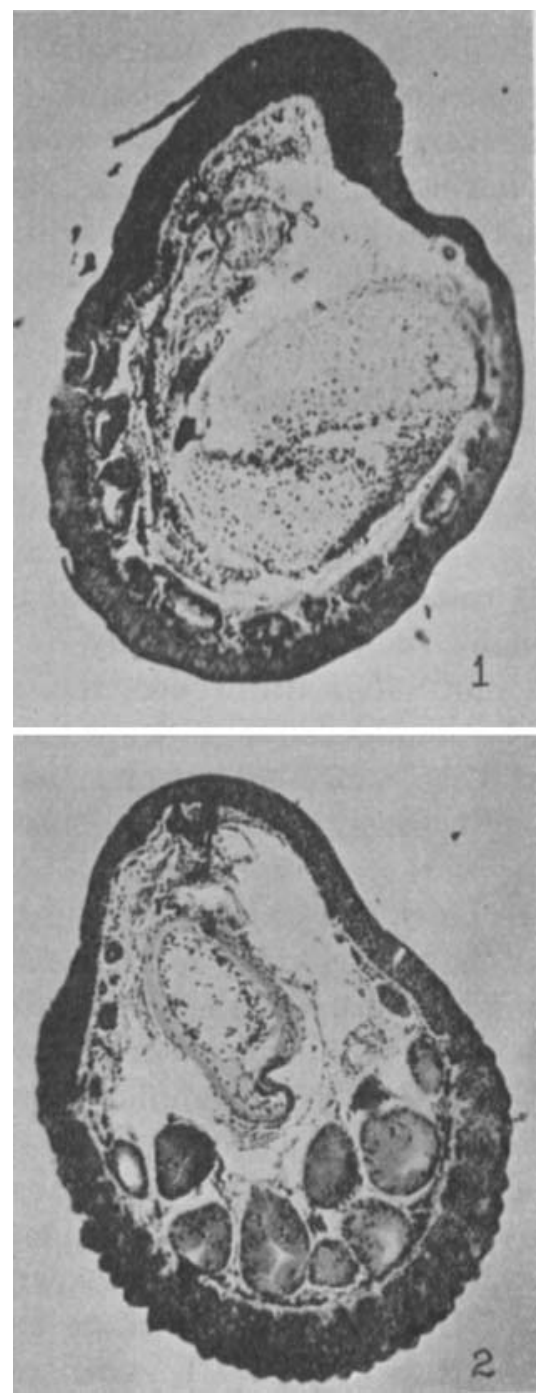

Fig. 1 A transverse section of the supplemental toe (second finger) of the intersexual frog. Note absence of epidermal papillae and the rudimentary condition of mucous glands.

Fig. 2 A transverse section of the supplemental toe of a normal male frog (killed October 10th), showing well-developed epidermal papillae and mucous glands. 
On the base of the mani there were definite swellings, in form similar to, in size, however, a little smaller than the finger pads of normal males. They were also pigmented in the usual male pattern, though only faintly so. Histologically, however, they were found to lack all projecting epidermal structures and their mucous glands were few and small (fig. 1). With respect to these two features, they showed a strong contrast to the condition so well displayed in most healthy males of this season (fig. 2). The webs of the hind feet are in most cases distinctly different in the two sexes: they are concave in females, whereas in males they may be convex or less concave than in the female. In our intersexual specimen the webs were nearly flat-margined, representing. in a way an intermediate condition between the extreme concavity in the female and convexity in the male.

\section{Accessory sex organs}

1. Male. The wolffian ducts originated on the dorsal surface of the kidney and became gradually shifted to its outer border, very close to the renal portal vein. Histologically, the ducts were lined with a columnar epithelium, which was in some places distinctly folded. These wolffian ducts were exceptionally small anteriorly, as compared with those of normal males; but they grew larger in caliber posteriorly. Below the kidneys they were swollen to form the usual seminal vesicles, both of which measured about $2 \mathrm{~mm}$. in length and were typically male in all respects. Behind the seminal vesicles the ducts ran inward, terminating by two separate openings into the cloaca.

Vasa efferentia were present on both sides. On the left side their number was not observed. On the right side there were ten vasa efferentia distributed over the entire length of the gonad. These did not branch much, only two or three of them bifurcating at acute angles just before entering the kidney.

2. Female. There were two rudimentary müllerian ducts extending from the summit of the seminal vesicles almost to 
the roots of the lungs, where the oviducts in females normally terminate. In length the right duct measured around $20 \mathrm{~mm}$., being longer than the left, which measured nearly $15 \mathrm{~mm}$. Both of these ducts were thin and delicate, becoming even more so as they proceeded forward. Both ran, for the middle one-third of their course, lateral to the kidneys, with which they were intimately associated by membranous connections and numerous fine cords. Behind the kidneys they were closely bound together with the wolffian ducts and appeared to merge into the seminal vesicles, and finally lost their external identity.

Neither one of the müllerian ducts possessed any dilatation and both were devoid of the characteristic convolutions of normal oviducts, only the right müllerian duct coiling for a short distance above the level of the kidneys. In the posterior two-thirds of the ducts, along their outer side, there were seen small pigmented masses of various shapes, the significance of which was not determined.

Macroscopically, the müllerian ducts showed no anterior opening into the body cavity. Subsequent microscopical examination of cross-sections of the ducts not only confirmed this, but further demonstrated that both ducts were mere solid cords in the anterior third of their course. Posteriorly, they possessed a tiny lumen, surrounded by a single layer of cuboidal cells, and were entirely devoid of any glandular structures. As mentioned previously, the left müllerian duct was shorter than the right; its lumen was also found to be smaller.

Although externally the müllerian ducts appeared to have fused with the seminal vesicles of the respective sides, yet sections of both wolffian ducts and müllerian ducts revealed that their lumina, although closely associated, were distinet and that in no place did they show any indication of fusion. They opened separately into the cloaca. The opening of the left müllerian duct was about $10 \mu$ anterior to that of the right one. About $0.12 \mathrm{~mm}$. posterior to the latter opening were found the orifices of the wolffian duets. 


\section{Primary sex characters}

In size the left gonad was larger than the right one. In length the former measured $4.8 \mathrm{~mm}$. and the latter, about $4.0 \mathrm{~mm}$.; widths and thicknesses were too irregular to allow measurements for comparison. In form the two gonads resembled neither testes nor ovaries. The left gonad was somewhat pear-shaped with ovum-like projections around its

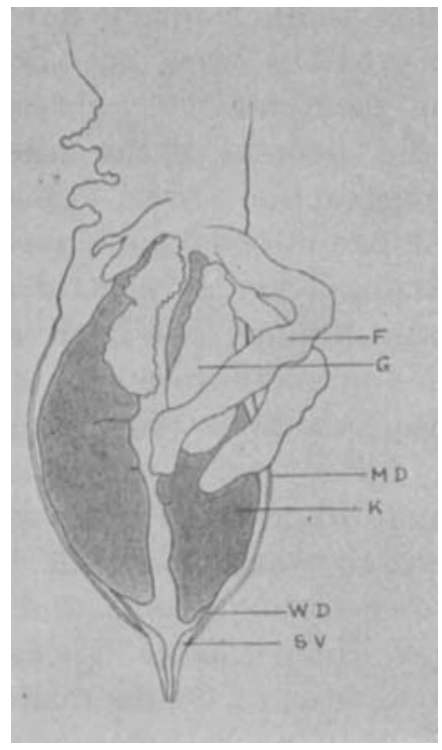

Fig. 3 A semidiagrammatic ventral view of the urogenital system, including parts of both fat-bodies. $F$, fat-body; $G$, gonad; $M D$, müllerian duet; $K$, kidney; $W D$, wolffian duct; $S T$, seminal vesicle. Figure outlined with the aid of a camera lucida. Magnification, approximately $\times 4$.

anterior pole and with numerous minute convexities in its larger posterior portion. These outside convexities were later found to correspond to the spermatic lobules inside. The right gonad was irregular in outline, with constrictions here and there, and showed protruding ova throughout its entire surface. The two gonads were not situated at the same level, the left one being a little behind the right. Both gonads were entirely free from pigmentation. 
With respect to the corpora adiposa, neither of them presented any unusual features. The right one was compact with but few lobes, while the left one was much more massive, with several big divergent branches, some of which turned backward and capped over the left gonad.

Upon sectioning, both gonads proved to be ovotestes. Their microscopical structures were as follows:

1. The left gonad was found to be composed of a larger testis portion, with a smaller ovary portion situated anteriorly. These two portions were not discrete and the line of junction between them was very irregular. Around the junctional region the stromal tissue was evidently hypertrophied. This hypertrophic stroma appeared to have penetrated for some distance into the substance of the testis portion along a longitudinal, nearly central axis of the gonad, and became gradually thinned out in divergent intertubular branches. Embedded in and throughout the main core of the stromal hyperplastic substance there were found irregular lobules of varying forms and sizes, containing male germ cells mostly in gonial stages. In one instance several tiny bunches of spermatozoa were observed, enclosed in a small space in the overgrown stromal tissue, and tightly surrounded by a heavy mesothelial investment. These phenomena might be interpreted as evidences of degeneration of the spermatic tissue by excessive growth and consequent sclerosis of its interstitium, followed by a deformity and degeneration of the spermatic tubules involved. But a detailed study of the entire gonad showed clearly that in the most posterior portion of the gonad the testicular tubules were well developed with spermatogonia and numerous spermatocytes. In its middle portion, where the stromal hyperplasia was most pronounced, there were found around the main core of the hyperplastic stroma many spermatic tubules in various degrees of formation. In these tubules spermatogonia and occasionally spermatocytes were in evidence. The most anterior portion of the gonad was essentially ovarian, but the stromal mesenchyme appeared to have invaded it from the testicular por- 
tion. In the stromal mesenchyme scattered follicles of male germ cells were detected. Their presence here authenticated an invasion of the testicular substance into the ovarian portion. The topography of the whole gonad seemed, thus, to indicate that the hyperplastic stromal tissue was withdrawn from the region where definitive spermatic tubules had been formed and was concentrating in those places where such tubules were being formed or were probably to be formed. This being the case, the conclusion seemed justified that the stromal hyperplasia was probably not a feature of degeneration, but was apparently functional in the organization of testicular structures by serving as a ground-substance in which the various elements of the germinal and somatic tissues aggregated themselves to form the spermatic tubules.

In this connection it should be mentioned that the stroma cells in the hypertrophied condition were structurally normal in all respects. They were without distinct cell boundaries, but each one of them possessed a well-defined nucleus. Their nuclei were always small, compact, and more or less elongated, and contained one, or occasionally two or three nucleoli and irregular strands of shadowy outline. In sharp contrast to this type, the spermatogonial nuclei were large, round or polymorphic in appearance, stained lightly, and contained, in most cases, an intricate network upon which were scattered here and there several distinct nucleoli, usually spherical and of large size.

Careful study of the male germ cells revealed nothing morphologically abnormal. Spermatogenesis was in progress and mitosis normal in every respect. However, except for a few small groups in abnormal position, spermatozoa were not found throughout the entire gland. In sections of normal testes of this season, well-developed spermatozoa were found abundant in the lumina of the seminiferous tubules.

In the ovary portion ova were numerous. But they were not all confined to this portion. Some were found among the testicular structures and even within the spermatic tubules. Such ova were morphologically identical with those in the 
ovary portion of the gonad, and being so entirely different from their neighboring male sex cells, with which they were not connected by any intermediate forms, naturally could not be regarded, at least from morphological evidence, as the products of the male germinal tissue. Rather they should

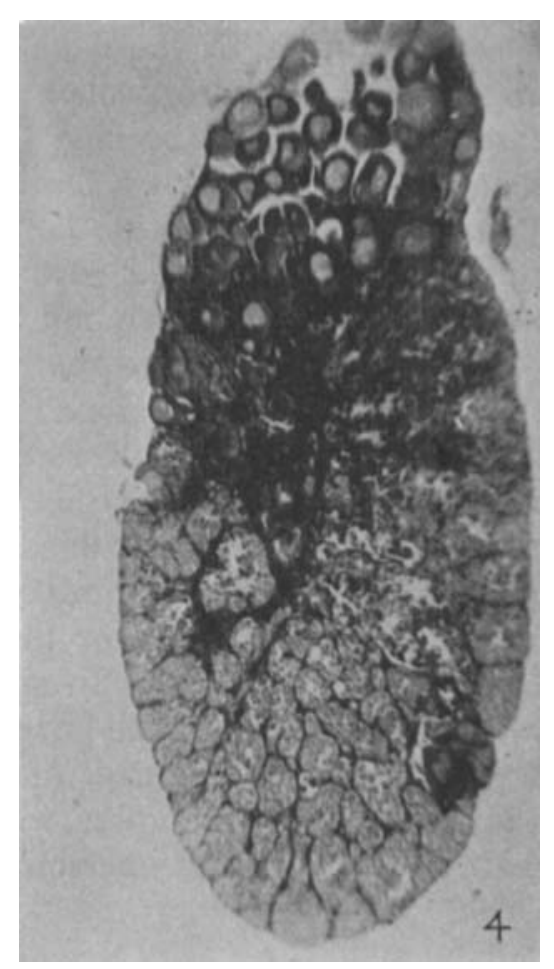

Fig. 4 A horizontal section of the left gonad, showing its ovotesticular structure. Note stromal hyperplasia in the middle region of the gonad, and testis-ova in different parts of the testis portion. Sections were eut at $8 \mu$ and stained with iron hematoxylin.

be considered the remains of previously existing ovarian tissue which had been replaced by spermatic tubules. The presence of an ovum in a seminal tubule did not result in any recognizable deformity of the male germ cells found therein, but the shape of the ovum seemed to be conditioned by the form of the tubule in which it was contained. 
Measurements of ova showed that their diameters varied from $100 \mu$ to about $250 \mu$, with the mean around $200 \mu$. All ova, when carefully examined, were found to be surrounded by a delicate capsule of flattened follicle cells which were stretched to an extreme thinness. The cytoplasm of the ova was homogeneous and stained grayish with iron hematoxylin.

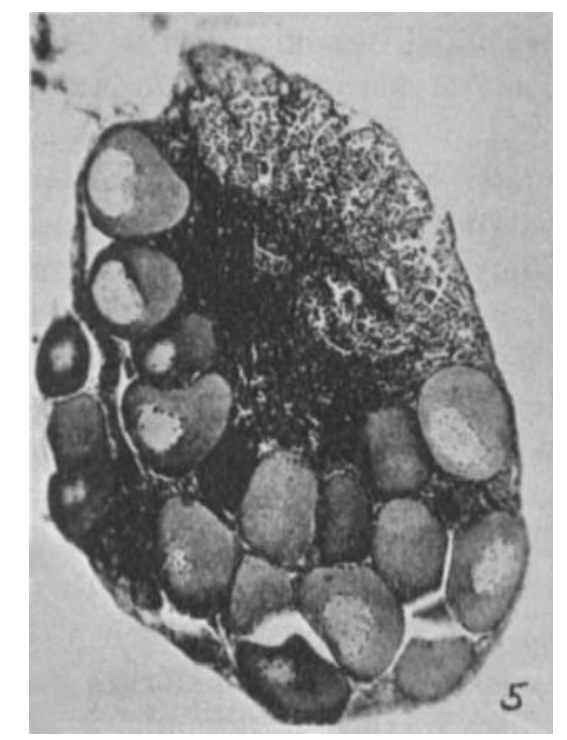

Fig. 5 A transverse section through the posterior part of the right gonad. Testicular structures are distinct in the dorsomedial portion of the gonad. Many primordial germ cells either singly or in lobules, which also contain spermatogonia, are found distributed in the hypertrophied stroma. Sections were eut at $10 \mu$ and stained with iron hematoxylin.

The nucleus stained only lightly and was generally round or oval with a sharply defined nuclear membrane. In the nucleus there were many intensely basophilic bodies of various sizes, more abundant toward the periphery than in the central portion. An intranuclear network of irregular, plumous filaments was quite distinct in some cases. The ova did not show any sign of true yolk formation. Apparently, owing to certain unfavorable conditions, they were prevented from undergoing functional development. In normal ova of this season 
yolk was formed in abundance, increasing the size of the ova to a diameter of over $1000 \mu$.

2 . In the right ovotestis the germinal tissue was everywhere ovarian, except for a small patch of spermatic substance. In the anterior portion of the gonad the interstitium was very scanty and loose, and the ova appeared to be 'floating' in the places they occupied. Posteriorly, the stromal tissue became distinctly hypertrophied in some places. In close association with the hyperplastic stroma one found many spermatic tubules, most of which were grouped along the dorsomedial border of the gonad. Similar to the condition in the left ovotestis, the excessive growth of the stromal tissue in this ovotestis was apparently not a sign of degeneracy, but was best regarded as associated with the generative process of the testicular structures. Histologically, the spermatic tubules were normal, only of small size, and the germ cells contained in them were mostly in primordial and gonial stages, though occasionally spermatocytes were found, but no spermatozoa. These conditions indicated that the seminal tubules were newly formed. Here and there in the hypertrophied stroma some tubules were seen still in the process of formation. The ova so abundant in this gonad were similar in structure to those in the left gonad. The follicular walls were distinct and intact, closely adhering to the cell surface. Pigmentation was absent.

\begin{tabular}{|c|c|}
\hline $\begin{array}{l}\text { Summary of the im } \\
\text { Male characteristics }\end{array}$ & $\begin{array}{l}\text { tant sex characters } \\
\text { Female characteristics. }\end{array}$ \\
\hline Presence of finger pads & Abundance of dermal papillae \\
\hline $\begin{array}{l}\text { Web condition of the hind limbs } \\
\text { male-like }\end{array}$ & Light body coloration \\
\hline Vasa efferentia on both sides & Two rudimentary müllerian ducts \\
\hline Two seminal vesicles & $\begin{array}{l}\text { Separate openings of the muillerian } \\
\text { ducts and the wolffian ducts into the } \\
\text { cloaca }\end{array}$ \\
\hline $\begin{array}{l}\text { Large testis portion in the left ovo- } \\
\text { testis }\end{array}$ & $\begin{array}{l}\text { Small ovary portion in the left ovo- } \\
\text { testis and many ova in the testis } \\
\text { portion of the same gonad }\end{array}$ \\
\hline spermatic tissue & $\begin{array}{l}\text { Large ovary portion in the right ovo- } \\
\text { testis }\end{array}$ \\
\hline
\end{tabular}




\section{DISCUSSION}

\section{Secondary sex characters}

From a superficial examination of the secondary sex characters, the above frog would be classed as a male, due to the presence of well-defined finger pads. However, sections of the pads show distinctly that they lack the characteristic papillae and glands found in the normal males. Careful inspection of other external features reveals also that the animal is not a normal male, but of an intersexual type.

A study of literature on genital abnormalities in frogs shows that most of the earlier writers on this subject neglected to describe carefully the external sex characters. In many accounts the authors merely mentioned the 'sex' of their specimens, based, in all probability, on a superficial examination of the presence or absence of the finger pads. Such diagnosis of sex is not adequate, as is shown in the present case.

Concerning the relationship between primary and secondary sex characters, it is noted that in our frog, despite the asymmetrical condition of the gonadic constituents, the secondary sex characters are developed in an almost perfectly symmetrical fashion. There is, thus, no side-to-side correlation between the primary sex characters and the secondary sex characters. But the intersexual condition of the latter is certainly correlated with the mixed constitution of the former.

\section{Accessory sex organs}

In our specimen vasa efferentia and seminal vesicles are both present. On the right side, vasa efferentia are found not only in connection with the testis portion, but also with the ovary portion of the ovotestis. Besides these male accessory sex organs, there are two rudimentary müllerian ducts, the left duct being the less developed. This asymmetry corresponds in a rough way to the relative amount of ovarian tissue in the respective gonads. Positive correlation between 
the degree of development of the müllerian ducts and the amount of the ovarian tissue in the gonads has been both affirmed and contradicted in specimens of intersexual frogs. In toads Sutton ('85) examined more than 250 specimens and found "as a rule, the amount of development of these Müllerian ducts is in direct proportion to the size of 'Bidder's organ'." Fuhrmann, from his extensive study of hermaphrodite toads, came to the conclusion that there was no correlation whatsoever between the development of the müllerian ducts and the condition of the ovaries in the hermaphrodites. Crew maintained that "the degree of development of the Müllerian duct is controlled to some extent by the activity of the ovary of the same side," and that in the process of sex reversal, "the appearance of the spermatic tissue is associated with the cessation of the activities of the ovaries and the further development of the Müllerian ducts is thereby prohibited. The degree of development of these ducts is some indication, therefore, of the relative time when the transformation of the gonads began." Witschi ('21) concluded from his observation on asymmetrical hermaphrodites that "somatische Geschlechtsmerkmale von den Keimdrüsen abhängig sein können, ohne dass eine innere Sekretion mitwirkt." In 1925, he further demonstrated that not only the müllerian ducts, but also the vasa efferentia and seminal vesicles showed "eine einseitige Korrelation zur Keimdrüse." With respect to our specimen, however, the seminal vesicles are similar on both sides, notwithstanding the differing amount and condition of the testicular tissue in the two gonads.

\section{Primary sex characters}

In literature the presence of two intersexual gonads in one frog has been recorded in many cases. In Rana temporaria, Marshall ('84), Kent (Crew)7 ('85), Latter ('90), Cole ('96),

'By 'Bidder's organ' the author referred to the rudimentary ovary or potential ovary in the normal toad, and not to the abnormal ovary as is found in the hermaphrodite toad.

'Kent's specimen was redescribed by Crew in 1921. 
Punnett ('00), Crew ('21 a), Witschi ('23), and Woronzowa ('26) reported cases where both gonads were microscopically demonstrated to be either ovotestes or ovum-containing testes. ${ }^{8}$ Ridewood ('88), Smith ('90), and Lloyd ('29) had specimens also of Rana temporaria, in which, upon external inspection, two ovotestes were present. Of these, however, no sections were made. In Rana esculenta, Crew described a specimen with two ovotestes, and Mitrophanow ('94) a frog, in which there were found two testes of unequal size, both containing doubtful ova; the right one, however, containing one true ovum and an anterior lobe which was regarded as a rudimentary Bidder's organ. In Rana viridis, Friedmann ('98 a) observed female elements in both testes of an adult specimen. In Rana fusca, Hooker ('12) and Boulangé ('14) found two ovotestes in intersexual individuals. In American species, Swingle ('17) mentioned that in a pseudohermaphrodite of Rana pipiens, both testes contained ripe spermatozoa and large oocytes. Clemens ('21) dissected a bullfrog which contained an ovotestis on the left side, while the right gonad had been destroyed before the hermaphroditic nature was discovered.

In most of the above-mentioned cases the ovarian tissues were regarded as pathological or degenerating, while the testicular tissues were considered normal. In our specimen, from a comparative study of the histological and cytological structures in the ovotestes and in normal gonads of the same season, it is shown that both ovarian and testicular tissues of the ovotestes, though apparently morphologically normal, are functionally underdeveloped. The spermatic tissue has failed to generate mature spermatozoa, while the ova show no sign whatsoever of true vitellogenesis. It has also been shown that the interstitial hyperplasia is not necessarily an actual feature of tissue degeneration, as so recorded in many cases, but is probably a factor in the formation of testicular struc-

\footnotetext{
${ }^{8}$ An ovotestis is composed of recognizable portions of ovary and testis, while an ovum-containing testis is mainly testicular in structure, eontaining an ovum, ova, or groups of ova in its spermatie substance.
} 
tures during their replacement of the ovarian tissue. If this is the case, we may interpret this frog as undergoing a sexual transformation toward maleness.

\section{General considerations}

Crew, in his attempt to explain a female-to-male sex reversal in frogs, has strongly contended that the spermatic tissue is dominant over the ovarian tissue and that the appearance of a small amount of the former is associated with the immediate degeneration of the latter. "Quantity, apparently, is not a factor, for a very small nodule of testicular substance can still provide sufficient of the male hormone to wipe out the great mass of ovarian tissue and its abundant internal secretion." In our frog the presence of two small müllerian ducts may be taken, in Crew's interpretation, as an indication that sex transformation toward maleness has become active during, if not before, the time of metamorphosis. Judging from the size and body build of the frog, it is at least three years from metamorphosis. If the process of sex transformation has been going on for three or four years, one would naturally expect, in accordance with Crew's notion of the dominancy of the male substance, a fully transformed individual with typical testes. But, on the contrary, we find two gonads still of ovotesticular structure and also that in the right gonad the male element occupies but a small portion, while the female element strongly predominates in quantity. Evidently, this case does not support Crew's contention of the absolute dominance of the male substance and indicates that the strength of both sex substances is conditioned by the environmental complex. Under certain environmental conditions, one sex may be favored in development, while the other tends to degenerate. Under certain other environmental conditions, it is conceivable that both sexes can suitably exist together for some time. Eventually, however, one sex or the other will gradually fade out of existence, depending upon which sex is favored in development, and not upon the alleged dominancy of any particular sex. 
The breeding experiments of Crew and Witschi on some hermaphrodite frogs seemed to show that those frogs were genetically females undergoing masculation. In our case the presence of finger pads and of well-developed vasa efferentia and seminal vesicles, as well as the prevailing tendency toward maleness in the gonads, may also be regarded as morphological indications of sex modification in the male direction. However, there are evidences in other amphibians that the male sex has actually become feminized. In Triton alpestris, Champy ('21) described a case of 'total sex inversion' from male to female. Caroli, among others, has noted that in toads certain parts of the testes sometimes develop in a female direction. Burns ('28) recently performed some transplantation experiments on Amblystoma, in which he removed a section of mesonephros, bearing the gonads, from a younger larva and inserted it into the body cavity of an older larva. His results showed that the male gonads of both graft and host were strongly modified: an ovarian cortex had appeared in the male graft by residence in a female host and, in at least one instance, in a male host through the presence of a large female graft. If we consider the sex condition in the frog as fundamentally similar to that in other amphibians, it seems logical, then, to assume that in frogs sex transformation toward femaleness might be a possibility.

In this connection, one should not neglect to consider the phenomenon of testis-ova, ${ }^{9}$ which has, in some respects, an important bearing upon the process of sex transformation. Crew contends that in all cases where ova are found in the spermatic tissue of the testis portion of an ovotestis and of an otherwise normal testis, such ova are but the remains of previously existing ovarian tissue, which has been replaced by the spermatic tissue. This condition appears to be true in our specimen. In the left gonad of our frog, along the junctional region between the ovary portion and the testis portion, many ova from the former portion are being included in the latter portion and become gradually surrounded by

\footnotetext{
${ }^{9}$ Testis-ova refer to ova or ovum-like bodies in an otherwise normal testicular tissue. 
the male germinal tissue. This phenomenon demonstrates the process of formation of the testis-ova. While contending for an ovarian origin of the testis-ova in our case, it should not be overlooked that in many other cases they are shown to be of testicular derivation. Meyns ('12) transplanted pieces of testis of one frog under the skin or into the body cavity of another. Such grafts, under favorable conditions, regenerated and the included germ cells developed into egglike cells. Meyns concluded that these ovum-like cells were really ova and had arisen from male-determined germ cells. Guyénot and Ponse ('23) also observed in toads the occurrence of ova in testes when the latter were transplanted or were regenerating after incomplete castration. Dubois and Beaumont ('27) observed a similar phenomenon in Triton. Champy ('13) found in the adult testes of frogs, during the 'période interspermatogénétique,' oviform cells, which may develop further "et aboutit à la formation d'ovocytes incontestables qu'on ne peut distinguer de ceux d'un jeune ovaire." These facts are sufficient indication that testis-ova are not always of ovarian origin, but are in some cases produced by the modification of sex cells of the testes along the female line.

An account of hermaphroditism in frogs naturally recalls the phenomenon of Pflüger's hermaphroditism. In the socalled undifferentiated races the young frogs show distinct hermaphroditic tendencies, and sex is not definitely differentiated until late in development. It is conceivable that some of the earlier accounts on intersexual gonads of frogs are but descriptions of certain stages of Pflüger's hermaphrodites. But in Rana cantabrigensis, or at least in the Ann Arbor strain of this species, Pflüger's hermaphrodites do not occur and the sexes are distinctly differentiated at an early larval period. The occurrence in this strain of an adult hermaphrodite has, therefore, no relation to Pflüger's hermaphroditism and is, in whatever respect it may be considered, an abnormal phenomenon, while Pflüger's hermaphroditism is essentially a normal embryonic condition in certain races of frogs. 
Lastly, it should be pointed out that in all abnormal hermaphrodites of frogs, including the one presented in this paper, which have been described as having undergone a sex transformation, or at least have been so interpreted, there is no knowledge whatsoever of the early history of the individuals. It is conceivable and probable that in these cases sex transformation may be initiated and induced by a defective sex differentiation in early embryonic development or by an abnormal hereditary mechanism of some kind. Crew makes a sweeping generalization when he says, "A gonad which previously had every character of a perfect ovary, has thus become replaced by a perfect testis," and again, "It is shown that the recorded cases of abnormality of the reproductive system illustrate the process by which an individual, at one time possessing solely the complete sex-equipment of the female, comes to exhibit the organization of the male." What evidence is there that these sexually abnormal frogs have ever possessed solely and normally complete sex organs of either one sex? Unless positive demonstration of this is furnished, we cannot speak of sex transformation of a normal frog in cases of abnormal hermaphroditism.

\section{ACKNOWLEDGMENTS}

I wish to acknowledge my indebtedness to Prof. Peter Okkelberg for his valuable advice, suggestions, and encouragement. I also want to express my gratitude to Mr. C. S. Chen and Dr. A. E. Woodhead for generous help in photographic work. 


\section{LITERATURE CITED}

Batbiani, G. 1879 Leģon sur la génération des Vertébrès.

Bhattacharya, D. R., ANd Das, B. K. 1920 Note on persistent oviducts and abnormal testes in a male, Rana tigrina. Jour. and Proc. Asiat. Soe. Bengal, vol. 16.

BOULANGÉ, H. 1914 Un cas d'hermaphrodisme vrai bilatéral chez Rana fusea. Fenille des Jeunes Naturalistes, T. 44.

BURNs, R. K., JR. 1928 The transplantation of larval gonads in urodele amphibians. Anat. Rec., vol. 39.

Caroli, A. 1926 a Variazioni e anomalie dell'organo di Bidder quale contributo all'ermafroditismo della gonade degli anfibi anuri. Atti. R. Accad. Fisiocritici Siena, ser. 9, 17.

$1926 \mathrm{~b}$ Lo studio dell'organo di Bidder in rapporto al tipo di variazione del Bufo vulgaris, Laur e B. viridis, Laur. Atti. R. Accad. Fisiocritici Siena, ser. 10, 1 .

$1926 \mathrm{c}$ Su un reperto di elementi germinati nel parenchima renale di Bufo viridis, Laur. Atti. R. Acead. Fisioeritiei Siena, ser. 10, 1.

1927 Recherches sur l'organe de Bidder des Bufonidés en rapport à l'étude de l'hermaphrodisme de la gonade des amphibies anoures. Arch. Ital. de Biol., vol. 78 .

Champy, C. 1913 Recherches sur la spermatogénèse des Batrachiens et les éléments aceessoires du testicule. Arch. de Zool. Expér. et Gén., T. 52. 1921 Changement expérimental du sexe ehez Triton alpestris. Cpt. Rend. Acad. Sei., T. 172.

Chidester, F. E. 1926 Incipient hermaphroditism in the bullfrog. Anat. Ree., vol. 34 .

Clemens, W. A. 1921 A case of complete hermaphroditism in a bullfrog (Rana eatesbiana). Anat. Rec., vol. 22.

CoLe, F. J. 1896 On a case of hermapliroditism in Rana temporaria. Anat. Anz., Bd. 11.

CREw, F. A. F. 1921 a A deseription of certain abnormalities of the reproductive system found in frogs, and a suggestion as to their possible siguificance. Proc. Roy. Phys. Soc. Edin., vol. 20.

$1921 \mathrm{~b}$ Sex-reversal in frogs and toads. A review of the recorded cases of abnormality of the reproductive system and an account of $A$ breeding experiment. Jour. Geneties, vol. 11.

Crew, F. A. E., ANd Feld, H. B. 1922 The nature of certain ovum-like bodies found in the seminiferous tubules. Quart. Jour. Mier. Sei., vol. 66 .

Cunningham, B., and Becton, C. 1926 The oceurrence of an ovotestis in Bufo terrestris. Jour. Elisha Mitehell Sci. Soc., vol. 42.

DaUvarT, A. 1926 Ein Fall von Hodenheterotopie bei Rana temporaria. Zeitschr. f. wiss. Biol., Abt. D., Bd. 108.

1927 Hétérotopie testiculaire chez la grenouille. Cpt. Rend. Soc. de Biol., T. 97.

Dornesco, G. T. 1926 Un cas de monorchidie congénitale chez Rana esculenta adulte. Ann. Sei. Univ, Jassy, T, 13.

1927 Un nouveau eas de monorchidie eongénitale chez Rana esculenta adulte. Ann. Sci. Univ. Jassy, T. 14. 
Dragoru, 1., ET Por, E. 1927 Un cas d'hermaphrodisme glandulaire chez la grenouille (Rana temporaria). Cpt. Rend. Soc. de Biol., T. 96.

Dubois, A. M., Ет Beaumont, J. 1927 Intersexualitê phénotypique dans la gonads mâle du Triton. Cpt. Rend. Soc. de Biol., T. 97.

Dubois, A. M., ET Ponse, K. 1927 Hypogénitalisme chez Rana esculenta. Cpt. Rend. Soe. de Biol., T. 97.

EgGerT, B. 1926 Die Geschlechtsmerkmale jm Lebenszyklus der männliehen und weiblichen Kröten (Bufo vulgaris Laur). I. Teil. Biddersches Organ, Keimdrüsen und Müllerseher Gang. Zeitschr. f. Anat. $u$. Entwgesch., Bd. 79 .

1927 Ueber sexuelle Unterschiede am Schädel der Erdkröte (Bufo vulgaris Laur) und ihr Verhalten bei der experimentellphysiologisehen Geschlechtsumstimmung. Zeitschr, f. wiss. Zool., Bd. 129.

1929 Der Hermaphroditismus der Tiere. I. Beitrag zur Intersexualität der Auuren. Zeitschr. f, wiss. Zool., Bd. 133.

Eismond, M. 1892 Coupe d'un ovaire, pas completement développé, de la grenouille (avee les signes extérieure mâles). Trav. du Labor. Zoot. de Varsovie, T. 7. (Original in Russian.)

Friedmann, F. 1898 a Ueber rudimentäre Eier in den Hoden von Rana viridis. Arch. f. mikr. Anat., Bd. 52.

$1898 \mathrm{~b}$ Beiträge zur Kenntniss der Anatomie und Physiologie der männlichen Geschlechtsorgane. Areh. f. mikr. Anat., Bd. 52.

Fumrmann, O. 1913 L'hermaphrodisme chez Bufo vulgaris. Rev. Suisse de Zool., T. 21.

Gertiartz, H. 1906 Multiplizität von Hoden nnd Leber. Anat. Anz., Bd. 28.

Goonali, S. 1908 Two cases of hermaphroditism. Jour. Anat. Physiol, vol. 42.

GUYḱNOT, E., ET PONSE, K. 1923 a Inversion expérimentale du type sexual dans la gonade du erapaud. Cpt. Rend. Soc. de Biol., T. 89.

$1923 \mathrm{~b}$ Noveaux résultats concernant le déterminisme des caractères sexuels secondaires du crapaud (Bufo vulgaris). Cpt. Rend. Soc. de Biol., T. 89 .

Harms, J. W. 1921 a Untersuchmoen über das Biddersche Organ der männlichen und weiblichen Kiröten. Zeitschr. f.. Anat. u. Entwgesch., Bd. 63.

1921 b Verwandlung des Bidderschen Organs in ein Ovarium beim Männchen von Bufo vulgaris. Zool. Anz., Bd. 53,

1926 Monographien aus dem Gesamtgebiet der physiologie der Pflanzen und der Tiere. Körper und Keimzellen I. Berlin, Verlag von Julius Springer.

Heymons, R. 1917 Ueber hermaphroditische Bildung bei einem Männchen von Rana temporaria. Sitzgsb. Ges. naturf. Freunde Berlin, Jahrg. 1917.

HoffMaNN, C. K. 1886 Zur Entwicklungsgeschichte der Urogenitalorgane bei den Anamia. Zeitsehr. f. wiss. Zool., Bd. 44.

Hooker, D. 1912 Der Hermaphroditismus bei Fröschen. Areh. f. mikr, Anat., Bd. 79.

IKEDA, S. 1896 Hermaphroditism in toads. Zool. Magazine (Organ of the Zool. Soc. of Tokyo), vol. 8. (Original in Japanese.)

KENT, A. F. S. 1885 A case of abnormal development of the reproductive organs in the frogs. Jour. Anat. Physiol., vol. 19. 
KING, H. D. 1910 Some anomalies in the genital organs of Bufo lentiginosus and their probable significance. Am. Jour. Anat., vol. 10.

Kuschakewitsch, S. 1911 Ein Fall von Hermaphroditismus lateralismus bei Rana esculenta. Anat. Anz., Bd. 38.

LATTER, O. H. 1890 Abnormal reproductive organs in Rana temporaria. Jour. Anat. Physiol., vol. 24.

Leigh-Sharpe, W. H. 1922 A curious case of a hermaphrodite frog. Amn. Mag. Nat. Hist., ser. 10, vol. 10.

Lloxd, J. H. 1921 Abnormalities in the common frog (Rana temporaria). Proe. Zool. Soe. London, 1921, 2.

1929 Hermaphroditism in the common frog (Rana temporaria). Am. Nat., vol. 63.

LoIset, G. 1901 Grenouille femelle présentant les caractères sexuels secondaire du mâle. Cpt. Rend. Soc. de Biol., T. 53.

Maclean, B. T. 1928 Abnormal organs in Rana pipiens. Anat. Rec., vol. 4.1.

Marshall, A. M. 1884 On certain abnormal conditions of the reproductive organs in the frogs. Jour. Anat. Physiol., vol. 18.

MatThews, J. D. 1885 Oviduct in an adult male skate. Jour. Anat. Physiol., vol. 19 .

MEYNs, R. 1912 Transplantationen embryonaler und jugendlicher Keimdrüsen auf erwachsene Individuen bei Anuren nebst einem Nachtrag über Transplantationen geschlechtsreifer Froschhoden. Arch. f. mikr. Anat., Bd. 79 .

Mrtrophanow, P. 1894 Un cas d'hermaphrodisme chez la grenouille. Bibliog. Anat., T. 2.

MüLLER, J. 1830 Bildungsgeschichte der Genitalien.

NEAL, H. V. 1924 A case of unilateral or true gynandromorphism in a leopard frog. Anat. Ree., vol. 29.

Nussbaum, M. 1906 Ueber den Einfluss der Jahreszeit des Alters und der Ernährung auf die Form der Hoden und Hodenzellen der Batrachier. Arch. f. mikr. Anat., Bd. 68.

1912 Der Bau und die zyklischen Veränderungen der Samenblasen von Rana fusca. Arch. f. mikr. Anat., Bd. 80.

PfLÜGer, E. 1882 Ueber die das Geschlecht bestimmenden Ursachen und die Geschlechtsverhältnisse der Frösche. Arch. f. d. gesam. Physiol. des Menschen u. der Thiere, Bd. 29.

OGNEw, S. J. 1906 Ein Fall von Hermaphroditismus bei Rana temporaria. Anat. Anz., Bd. 29.

OORDT, G. J. vAN 1923 Demonstratie van ein volwassen testis van Rana fusca, waarin een groot aantal eieren geworden wordt. Nederl. Tijdschrift. voor Geneeskunde, vol. 66.

Patzelt, V. 1918 Ueber verschiedene Missbildungen beim Frosche. Areh. $f$. Entw.-Mech. d. Organ., Bd. 44.

1923 Hypoplasie der Keimdrïsen und das Verhalten der Zwisehenzellen bei Rana esculenta. Arch. f. mikr. Anat., Bd. 100.

Punnetr, R. C. 1900 Note on a hermaphrodite frog. Anm. Mag. Nat. Hist., ser. 7 , vol. 6 . 
RaU, A. S., And Gatenby, J. B. 1923 Notes on the distribution, morphology and cytology of the organ of Bidder. Jour. Roy. Micr. Soc. London, $1923,1$.

RIDEwood, W. G. 1888 On an abnormal genital system in a male of the common frog. Anat. Anz., Bd. 3.

Shaw, M. E., and Rogers Brambelt, F. W. 1928 An aberrant ovary in a frog. Jour. Roy. Mier. Soc. London, ser. 3, vol. 48.

Sмгтн, W. R. 1890 A case of hermaphroditism in a common frog. Jour. Anlat. Physiol., vol. 24.

Spengel, J. $\dot{W} .1876$ Das Urogenital System der Amphibien. Arbeiten d. Zool.-zoot. Instituts Würzburg, Bd. 3.

1884 Fermaphroditismus bei Amphibien. Biol. Centralbl., Bd. 4.

STOHLER, R. 1928 Cytologische Untersuchungen an den Keimdrüsen mitteleuropäischer Kröten. Zeitschr. f. Zellf. u. mikr. Anat., Bd. 7.

Sutton, J. B. 1885 Diseases of the reproductive organs in frogs, birds and mammals. Jour. Anat. Physiol., Bd. 19.

SWINGLE, W. W. 1917 The accessory chromosome in a frog possessing marked hermaphroditic tendencies. Biol. Bull., vol. 33.

1922 Is there a transformation of sex in frogs? Am. Nat., vol. 56. 1926 The germ cells of anurans. II. An embryological study of sex differentiation in Rana catesbiana. Jour. Morph. and Physiol., vol. 41 .

TAKafashi, N. 1915 Ueber die Geschlechtsdrüsen der Wirbeltiere. I. Mitteil. Mitteil. d. medizin. Gesellsch. zu Tokio, Bd. 29.

1919 Ueber die Geschlechtsdrüsen der Wirbeltiere. II. Mitteil. Mitteil. d. medizin. Fak, d. Kaiser. Univ. zu Tokyo, Bd. 22.

Witscili, E. 1914 Experimentelle Untersuchungen über die Entwicklungsgesehichte der Keimdrüsen von Rana temporaria. Arch. f. mikr. Anat., Bd. 85 .

1921 Der Hermaphroditismus der Frösche und seine Bedeutung für das Geschlechtsproblem und die Lehre von der inneren Sekretion der Keimdrüsen. Arch. f. Entw.-Mech. d. Organ., Bd. 49.

1923 Ueber die genetische Konstitution der Froschzwitter. Biol. Zentralbl., Bd. 43.

1924 Die Beweise für die Umwandlung weiblicher Jungfrösche in männliche nach uteriner Ueberreife der Eier. Arch. f. mikr. Anat. u. Entw., Bd. 102.

1925 Studien über Geschlechtsumkehr und sekundäre Geschlechtsmerkmale der Amphibien. Arch. d. Julius Klaus-Stiftung f. Vererbungsforschung, Sozialanthropologie und Rassenhygiene, Bd. 1.

1925 Beziehungen zwischen primären und sekundären Geschlechts merkmalen, die nicht durch Hormone vermittelt sind. Schweiz. med. Wochschr, Bd. 55.

Woronzowa, M. A. 1926 Fall von Hermaphroditismus bei Rana temporaria. Trudy Labor. Eksper, Biol. Zoopark Moseow, T. 2.

Yuna, E. 1907 Sur un cas d'hermaphrodisme chez la grenouille. Rev. Suisse de Zool., T. 15. 